\title{
ANALISIS TRANSPARANSI DALAM PENYELENGGARAAN PELAYANAN PUBLIK DI KANTOR DINAS PENANAMAN MODAL DAN PELAYANAN SATU PINTU KABUPATEN BONE
}

\author{
Marjana Fahri \\ Fakultas Syariah dan Hukum Islam IAIN Bone \\ Email: Marjana_fahri@yahoo.com
}

\begin{abstract}
Transparency of service is very important for government agencies in the provision of public services, because with the transparency of services so the public can easily find information or access about procedures in services provided olen government agencies. This study aims to describe, measure and analyze the Transparency of Public Service in the Office of Investment and Service of One Door of Bone Regency. This research is a qualitative research, approach method used is approach (social legal reserarch), data collection is done through interview, observation and documentation to informant in applying of transparency of public service. data analysis includes data reduction, data presentation and conclusion. The results of the research show that the application of transparency of the One Bint Department of Investment and Service Bone District has not been fully implemented in the indicator of service transparency expected by the service recipients such as Authorized and Responsible Officials there are still some authorities who have not yet fully know what they should do so much training is needed that can encourage transparency. Constraints faced by the internet network factors are not adequate so slow in the process of service delivery.
\end{abstract}

\section{Keywords: Transparency, Service}

\section{Abstrak}

Transparansi pelayanan sangat penting bagi instansi pemerintah dalam penyelenggaraan pelayanan publik, karena dengan adanya transparansi pelayanan maka masyarakat dapat dengan mudah mengetahui informasi atau akses tentang prosedur-prosedur dalam pelayanan yang diberikan olen instansi pemerintah. Penelitian ini bertujuan untuk, mengambarkan, mengukur dan menganalisa Transparansi Penyelenggaraan Pelayanan Publik Di Kantor Dinas Penanaman Modal dan Pelayanan Satu Pintu Kabupaten Bone. Penelitian ini merupakan penelitian kualitatif, Metode pendekatan yang digunakan adalah pendekatan hukum sosial (sosial legal reserarch), pengumpulan data dilakukan melalui wawancara, observasi dan dokumentasi terhadap informan dalam penerapan transparansi pelayanan publik. Analisis data meliputi reduksi data, penyajian data dan penarikan kesimpulan. Hasil penelitian menujukkan bahwa penerapan transparansi Dinas Penanaman Modal dan Pelayanan Satu Pintu Kabupaten Bone tidak sepenuhnya diterapkan, hal ini dapat diukur dari indikator transparansi pelayanan yang diharapkan oleh penerima layanan, seperti beberapa aparat yang berwenang tidak sepenuhnya memahami dan mengetahui apa yang mereka harus 
lakukan sehingga sangat dibutuhkan pelatihan yang dapat mendorong terlaksananya transparansi. Kendala yang dihadapi yaitu faktor jaringang internet yang tidak memadai sehingga lambat dalam proses penyelenggaraan pelayanan.

\section{Kata kunci : Transparansi, Pelayanan}

\section{A. Pendahuluan}

Pelayanan publik menjadi sorotan tajam dalam penyelenggaraan pemerintahan Indonesia, Hal ini tidak hanya terjadi di lingkup Pemerintah Pusat dan Pemerintah Daerah, namun terjadi pula di lingkup Badan Usaha Milik Negara maupun Badan Usaha Milik Daerah. Dalam merespon hal tersebut dan guna memperbaiki kualitas dan citra instansi pemerintah dimata masyarakat, maka perbaikan dan penataan pelayanan terus mengalami perubahan sebab tugas pokok pemerintah yang terpenting adalah berkewajiban dan bertanggung jawab untuk memberikan pelayanan yang terbaik dan profesional kepada masyarakat. Untuk itu dipertengahan tahun 2009, salah satu langkah konrit yang diambil pemerintah adalah mensahkan Undang-Undang No. 25 Tahun 2009 tentang Pelayanan Publik. Di dalam UU tersebut dijelaskan bahwa yang dimaksud dengan pelayanan publik adalah kegiatan atau rangkaian kegiatan dalam rangka pemenuhan kebutuhan pelayanan sesuai dengan peraturan perundang-undangan bagi setiap warga negara dan penduduk atas barang, jasa dan/atau pelayanan administratif yang disediakan oleh penyelenggara pelayanan publik. ${ }^{1}$

Dengan lahirnya UU ini maka diharapkan sistem pemerintahan yang baik (good governance) dapat terwujud dengan jalan meningkatkan efektivitas fungsi pemerintahan yang dilaksanakan oleh pemerintah itu sendiri maupun korporasi sehingga dapat berimplikasi terhadap penguatan demokrasi dan pemenuhan hak asasi manuasia, serta memperdalam kepercayaan masyarakat pada pemerintahan dan administrasi publik.

Penyelenggaraan pemerintahan akan lebih optimal apabila diikuti dengan Pelayanan Publik yang transparan dan akuntabel. Transparansi adalah prinsip

${ }^{1}$ Pasal 1 UU No. 25 Tahun 2009 tentang Pelayanan Publik 
yang menjamin akses atau kebebasan bagi setiap orang untuk memperoleh informasi tentang penyelenggaraan pemerintahan, yakni informasi tentang kebijakan, proses pembuatan dan pelaksanaannya, serta hasil-hasil yang dicapai. ${ }^{2}$ Transparansi dibangun atas dasar arus informasi yang bebas. Seluruh proses pemerintahan, lembaga-lembaga dan informasi perlu dapat diakses oleh pihakpihak yang berkepentingan, dan informasi yang tersedia harus memadai agar dapat dimengerti dan dipantau. ${ }^{3}$

Transparansi dapat dipahami sebagai kebebasan dalam memperoleh informasi yang mudah diakses oleh masyarakat, dan adanya pengawasan dengan partisipatif dari masyarakat. Berdasarkan Keputusan Menteri Pendayagunaan Aparatur Negara No. 26 Tahun 2004 tentang Petunjuk Teknis Transparansi dan Akuntabilitas dalam penyelenggaraan pelayanan publik meliputi: (1) prosedur pelayanan; (2) persyaratan teknis dan administrasi pelayanan; (3) rincian biaya pelayanan; (4) pejabat yang berwenang dan bertanggung jawab; (5) lokasi pelayanan; (6) janji pelayanan; (7) standar pelayanan dan, (8) informasi pelayanan. $^{4}$

Prinsip transparansi menciptakan kepercayaan timbal-balik antara pemerintah dan masyarakat melalui penyediaan informasi dan menjamin kemudahan didalam memperoleh informasi yang akurat dan memadai. Apabila dalam suatu instansi pemerintahan tidak transparan maka akan menimbulkan hilangnya kepercayaan masyarakat terhadap pemerintah, kurangnya partisipasi masyarakat terhadap kebijakan pemerintah, krisis moral dan akhlak yang berdampak pada pelanggaran hak asasi manusia. Pelayanan pada umumnya diberikan melalui beberapa birokrasi pemerintah. birokrasi bertanggung jawab dalam pelaksanaan kebijakan-kebijakan publik yang dirancang untuk menciptakan kesejahteraan masyarakat. Salah satu birokrasi pemerintah bergerak dalam

2 Krina, 2003, Indikator dan alat ukur prinsip Akuntabilitas, Transparansi dan Partisipasi. Sekertariat Good Governance BPPN, Jakarta, hlm.18

3 Tahir, 2011, Kebijakan Publik dan Transparansi Penyelenggaraan Pemerintahan Daerah ,PT. Pustaka Indonesia Press, Gorontalo, hlm.165

4 Keputusan Menteri Pendayagunaan Aparatur Negara No. 26 Tahun 2004 tentang Petunjuk Teknis Transparansi dan Akuntabilitas dalam penyelenggaraan pelayanan 
pelayanan publik adalah Dinas Penanaman Modal Dan Pelayanan Satu Pintu Kabupaten Bone dengan jenis pelayanan mengenai izin mendirikan bangunan, izin Trayek, izin tenaga kesehatan, izin sarana kesehatan, izin penelitian, izin lingkungan, izin lokasi, izin reklame, izin usaha jasa konstruksi, izin usaha pembudidayaan ikan, SIUP dan TDP, tanda daftar perusahaan, tanda daftar gudang dan IUI dan TDI.

Proses pelayanan publik harus mengedepankan prinsip transparansi kepada masyarakat agar tidak terjadi keluhan dan anggapan negatif dari masyarakat yang mendapatkan pelayanan. Berdasarkan uraian di atas maka penulis tertarik mengangkat judul "Analisis Transparansi Dinas Penanaman Modal Dan Pelayanan Satu Pintu Kabupaten Bone ”

\section{Rumusan Masalah}

1. Bagaimana Penerapan Transparansi Dalam Penyelenggaraan Pelayanan Publik Di Dinas Penanaman Modal Dan Pelayanan Satu Pintu Kabupaten Bone?

2. Kendala-Kendala apa yang dihadapi dalam peyelenggaraan pelayanan publik Di Dinas Penanaman Modal Dan Pelayanan Satu Pintu Kabupaten Bone?

\section{Tujuan Penelitian}

1. Untuk menganalisis Penerapan Transparansi Dalam Penyelenggaraan Pelayanan Publik Di Dinas Penanaman Modal Dan Pelayanan Satu Pintu Kabupaten Bone.

2. Untuk menganalisis Kendala yang dihadapi dalam peyelenggaraan pelayanan publik Di Dinas Penanaman Modal Dan Pelayanan Satu Pintu Kabupaten Bone.

\section{Kegunaan Penelitiani}

1. Sebagai kontribusi kepada pemerintah dalam menerapkan prinsip-prinsip transparansi dalam penyelenggaraan pelayanan publik khususnya Dinas Penanaman Modal Dan Pelayanan Satu Pintu Kabupaten Bone.

2. Sebagai sumbangan pemikiran dalam rangka pengembangan ilmu hukum khususnya ilmu hukum administrasi Negara. 


\section{B. Tinjauan Pustaka}

Mustopa menjelaskan bahwa yang dimaksud transparansi adalah keterbukaan pemerintah dalam membuat kebijakan-kebijakan sehigga dapat diketahui oleh masyarakat. Transparansi pada akhirnya akan menciptakan akuntabilitas antara pemerintah dengan rakyat. ${ }^{5}$ Selanjutnya transparansi juga memiliki arti keterbukaan organisasi dalam memberikan informasi yang terkait dengan aktivitas pengelolaan sumber daya publik kepada pihak-pihak yang menjadi pemangku kepentingan. ${ }^{6}$ Jadi transparansi memilki makna keterbukaan organisasi pemerintah dalam memberikan informasi mengenai penyelenggaraan pemerintahan. Transparansi adalah prinsip yang menjamin akses atau kebebasan bagi setiap orang untuk memperoleh informasi tentang penyelenggaraan pemerintah, yakni informasi tentang kebijakan, proses pembuatan serta hasil yang dicapai. ${ }^{7}$ Dari beberapa pengertian diatas, maka dapat ditarik kesimpulan bahwa transparansi merupakan hak masyarakat untuk mengakses informasi yang bebas, siap tersedia dan akurat yang berhubungan dengan pengelolaan rumah tangga di pemerintahan daerah sehingga akan menyebabkan terciptanya pemerintahan daerah yang baik dan memikirkan kepentingan masyarakat.

\section{Indikator Transparansi}

Menurut Adrianto Transparansi publik adalah suatu keterbukaan secara sungguh-sungguh, menyeluruh, dan memberi tempat bagi partisipasi dari seluruh

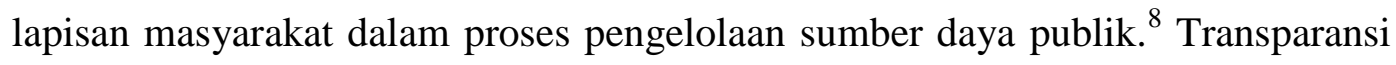
penyelenggaraa pelayanan publik merupakan pelaksanaan tugas dan kegiatan yang bersifat terbuka bagi masyarakat dari proses kebijakan, perencanaan, pelaksanaan dan pengawasan/pengendalian oleh masyarakat.Kegiatan tersebut harus dapat diinformaskan dan mudah diakses oleh masyarakat. Adapun transparansi penyenggaraan pelayanan Publik meliputi:

\footnotetext{
${ }^{5}$ Mustopa didjaja, 2003, Manajemen Proses Kebijakan Publik formulasi, implemntasi dan Evaluasi Kinerja, Lembaga Administrasi Republik Indonesia, hlm. 261

6 Mahmudi, 2010, Manajemen Keuangan, Airlangga, Jakarta, hlm. 17-18

${ }^{7}$ Lalolo Kriana P, 2003, Indikator dan alat ukur prinsip akuntabilitas, Transparansi dan partisipasi, Sekertariat Good Public Governance, Badan Perencanaan Pengembangan Nasional, Jakarta, hlm.13.

${ }^{8}$ Nico Adrianto, 2007, Good-e Governance: Transparansi dan Akuntabilitas Publik Melalui e-Governance, Bayumedia Publishing, Malang, hlm.23.
} 


\section{Prosedur Pelayanan}

Prosedur pelayanan adalah rangkaian proses atau tata kerja yang berkaitan satu sama lain, sehingga menunjukan adanya tahapan secara jelas dan pasti serta cara-cara yang harus ditempuh dalam rangka penyelesaian sesuatu pelayanan. Prosedur pelayanan publik harus sederhana, tidak berbelit-belit, mudah dipahami dan mudah dilaksanakan serta diwujudkan dalam bentuk Bagan Alir (Flow Chart) yang dipampang dalam ruangan pelayanan.

\section{Persyaratan Teknis dan Administratif Pelayanan}

Untuk memperoleh pelayanan, masyarakat harus memenuhi persyaratan yang telah ditetapkan oleh pemberi pelayanan, baik berupa persyaratan teknis dan atau persyaratan administratif sesuai dengan ketentuan peraturan perundangundangan. Dalam menetukan persyaratan, baik teknis maupun administratif harus seminimal mungkin dan dikaji terlebih dahulu agar benar-benar sesuai dan relevan dengan jenis pelayanan yang akan diberikan. Harus dihilangkan segala persyaratan yang bersifat duplikasi dari instansi yang terkait dengan proses pelayanan. Persyaratan tersebut harus diinformasikan secara jelas dan diletakkan didekat loket pelayanan, ditulis dengan hurup cetak dan dibaca dalam jarak pandang minimum tiga meter atau sesuai dengan kondisi ruangan.

\section{Rincian Biaya pelayanan}

Biaya pelayanan adalah segala biaya dan rinciannya dengan nama atau sebutan apapun sebagai atas pemberian pelayanan umum yang besaran dan tata cara pembayarannya ditetapakan oleh pejabat yang berwenang sesuai dengan ketentuan peraturan perundang-undangan. Transparansi mengenai biaya dilakukan dengan mengurangi semaksimal mungkin pertemuan secara personal pemohon/penerima pelayanan dengan pemberi pelayanan. Unit pemberi pelayanan seyogyanya tidak menerima pembayaran secara langsung dari penerima pelayanan.pembayaran hendaknya diterima oleh unit yang bertugas mengelola keuangan/bank yang ditunjuk oleh pemerintah/unit pelayanan. Disamping itu, 
setiap pungutan yang ditarik dari masyarakat harus disertai dengan tanda bukti resmi sesuai dengan jumlah yang dibayarkan.

\section{Pejabat yang Berwenang dan Bertanggung Jawab}

Pejabat/petugas yang berwenang dan bertanggung jawab memberikan pelayanan dan menyelesaikan keluhan, diwajibkan memakai tanda pengenal dan papan nama di meja/tempat kerja petugas. Pejabat/petugas tersebut harus ditetapakan secara formal berdasarkan surat keputusan/surat penugasan dari pejabat yang berwenang. Pejabat/petugas yang memberikan pelayanan dan menyelesaikan keluhan harus dapat menciptakan citra positif terhadap penerima pelayanan dengan memperhatikan; (a) Aspek psikologi dan komunikasi, serta perilaku melayani; (b) Kemampuan melaksanakan empati terhadap penerima pelayanan, dan mengubah keluhan pelayanan menjadi seniman; (c) Menselaraskan cara penyampaian layanan melalui nada, tekanan, dan kecepatan suara, sikap tubuh, mimik, dan pandangan mata; (d) Mengenal siapa dan apa yang menjadi penerima pelayanan; (e) Berada ditempat yang ditentukan pada waktu dan tempat pelayanan.

\section{Janji Pelayanan}

Akta atau janji pelayanan merupakan komitmen tertulis unit kerja pelayanan instansi pemerintah dalam menyediakan pelayanan kepada masyarakat. Janji pelayanan tertulis secara jelas, singkat dan mudah di menegerti, menyangkut hal-hal yang esensial dan informasi yang akurat, termasuk di dalamnya mengenai standar kualitas pelayanan.

\section{Standar Pelayanan}

Setiap unit pelayanan instansi pemerintah wajib menyusun standar pelayanan sesuai dengan tugas dan kewenangan masing-masing dan dipublikasikan kepada masyarakat sebagai jaminan adanya kepastian bagi penerima layanan. Standar pelayanan yang ditetapkan hendak realistis, karena merupakan jaminan bahwa janji/komitmen yang dibuat dapat dipenuhi, jelas dan mudah dimengerti oleh para pemberi dan penerima pelayanan. 


\section{Lokasi Pelayanan}

Tempat dan lokasi pelayanan diusahakan harus tetap dan tidak berpindahpindah, mudah dijangkau oleh pemohon pelayanan, dilengkapi dengan sarana dan prasarana yang cukup memadai termasuk penyediaan sarana telekomunikasi dan informatika (telematika).

\section{Informasi Pelayanan}

Untuk memenuhi kebutuhan informasi pelayanan kepada masyarakat, setiap unit pelayanan instansi pemerintah, wajib mempublikasikan mengenai prosedur, persyaratan, biaya, waktu, standar, akta/janji, motto pelayanan, lokasi serta pejabat/petugas yang berwenang dan bertanggung jawab sebagaimana telah diuraikan diatas.

Konsep transparansi dalam pelayanan publik menunjukan pada keadaan dimana segala aspek dari proses penyelenggaraan pelayanan bersifat terbuka dan dapat diketahui dengan mudah oleh para pengguna dan stakeholder yang membutuhkan. Jika segala aspek proses penyelenggaraan pelayanan seperti persyaratan, biaya dan waktu yang diperlukan, cara pelayanan serta hak dan kewajiban penyelenggara dan dipahami oleh publik, maka praktik penyelenggaraan pelayanan dapat dinilai transparan. ${ }^{9}$

\section{Metode Penelitian}

\section{Metode Pendekatan}

Penelitian social legal research adalah penelitian yang dilakukan dengan pendekatan pada realitas hukum dalam masyarakat. penelitian ini didasarkan pada adanya gejala berupa kesenjangan antara harapan (das solen) dengan kenyataan (das sein). ${ }^{10}$

Penelitian ini penelitian kualitatif dengan metode analisis deskriptif, yaitu penelitian yang memaparkan apa yang terjadi di lapangan atau wilayah tertentu. ${ }^{11}$ penelitian deskriptif ini digunakan untuk mengetahui Penerapan Transparansi

9 Dwiyanto, Agus, 2008, Mewujudkan Good Governance Melalui Pelayanan Publik, Gajah Mada Univertity Press, Yogyakarta, hlm 238.

10 Syahruddin Nawi, 2014, Penelitian Hukum Normatif Versus Penelitian Hukum Empiris, PT Umitoha Ukhuwa Grafika, Makassar, hlm. 8-9.

${ }^{11}$ Suharsini Arikunto, 2010, Prosedur Penelitian Suatu Pendekatan Praktek, PT. Rineka Cipta, Jakarta, hlm.198. 
Dalam Penyelenggaraan Pelayanan Publik Di Dinas Penanaman Modal Dan Pelayanan Satu Pintu Kabupaten Bone. Adapun tujuan penelitian kualitatif deskriptif adalah untuk membuat gambaran secara sistematis, faktual, dan akurat mengenai fakta-fakta yang sedang/telah diteliti. ${ }^{12}$

\section{Tempat Penelitian}

Tempat dan waktu penelitian ini dilaksanakan di Penerapan Transparansi Dalam Penyelenggaraan Pelayanan Publik di Dinas Penanaman Modal dan Pelayanan Satu Pintu Kabupaten Bone.

\section{Sumber Penelitian}

Sumber data dalam penelitian kualitatif adalah kata-kata dan tindakan, selebihnya adalah data tambahan seperti dokumen dan lain-lain. Secara umum sumber data yang digunakan dalam penelitian ini terdiri atas dua, yaitu: ${ }^{13}$ Data Primer yaitu data yang diperoleh dengan sumber-sumber tidak tertulis atau data lapangan melalui wawancara mendalam (indepth interview) kepada informan; Data Sekunder yaitu diperoleh melalui sumber-sumber tertulis. Strategi ini dilakukan untuk dapat membangun sebuah abstraksi tentang tujuan penelitian yang didukung oleh data yang dikumpulkan dan saling berhubungan, sehingga sifat penyusunannya adalah dari kesimpulan umum ke khusus.

\section{Teknik Pengumpulan Data}

Pengumpulan Data untuk memperoleh data yang benar dan akurat dalam penelitian ini maka peneliti menempuh prosedur sebagai berikut: ${ }^{14}$ Studi kepustakaan (Library Reserch) adalah mengumpulkan data yang dilakukan secara membaca, mengutip, mencatat dan memahami berbagi literatur, peraturan perundang-undangan dan peraturan lainnya baik buku-buku literatur ilmu hukum serta tulisan-tulisan lainnya yang relevan dengan permasalahan yang akan diteliti; Studi Lapangan (Field Reasearce)adalah mengumpulkan data yang dilakukan

\footnotetext{
${ }^{12}$ Sugiyono, 2009, Metode Penelitian Kuantitatif,Kualitatif, dan R\&D Alfabeta, Bandung hlm. 218 .

${ }^{13}$ Moleong, Lexy J, 2012, Metodologi Penelitian Kualitatif, Remaja Rosda Karya, Bandung, hlm. 157.

${ }_{14}$ Zainuddin Ali,2011, Metode Penelitian Hukum, Sinar Grafika, Jakarta, hlm. 176.
} 
dengan mengadakan penelitian langsung pada tempat atau objek penelitian dengan Wawancara, Observasi dan Dokumentasi.

\section{Teknik Analisis Data}

Teknik analisis data menggunakan uraian kalimat dengan menjelaskan hubungan antara teori dengan yang ada dilapangan mengenai Penerapan Transparansi Dalam Penyelenggaraan Pelayanan Publik di Dinas Penanaman Modal dan Pelayanan Satu Pintu Kabupaten Bone. Metode analisis kualitatif, yaitu suatu metode analisis data yang menggunakan dan memahami kebenaran yang telah diperoleh dari hasil penelitian untuk dicari hubungan antara satu dengan yang lain kemudian disusun secara sistematis dengan menggunakan tiga komponen yaitu reduksi data (penyederhanaan data), penyajian data, dan penarikan kesimpulan. ${ }^{15}$

Reduksi data atau proses eliminasi (pemilihan), yang berpusat pada penyederhanaan dari data yang diperoleh dilapangan atau menghilangkan datadata yang dirasa tidak penting; Penyajian data adalah hasil dari penelitian di lapangan yang disajikan dengan berbagai macam bentuk seperti rekaman, teks narasi, bagan dan grafik. Semua itu disimpulkan mejadi satu bentu teks deskripsi agar mudah dipahami oleh orang banyak dengan menggunakan uraian kalimat mengenai hubungan antara teori dengan yang ada dilapangan khususnya penarikan kesimpulan merupakan hal yang penting dalam setiap penelitian. Dalam penarikan kesimpulan ini yang perlu diperhatikan oleh peneliti yaitu menyusun secara sistematis hasil yang diperoleh dilapangan. Setelah itu diverifikasi kemudian di uji kevaliditannya.

\section{Hasil Penelitian dan Pembahasan}

Transparansi dalam penyelenggaraan pelayanan Dinas Penanaman Modal dan Pelayanan Satu Pintu Kabupaten Bone

\footnotetext{
${ }^{15}$ Amiruddin dan Zainal Asikin, 2008, Pengantar Metode Penelitian Hukum, Grafindo Persada, Jakarta, hlm.11
} 
Analisis Prosedur Pelayanan adalah serangkain proses yang harus dilewati oleh masyarakat. Prosedur pelayanan di Dinas Penanaman Modal dan Pelayanan Satu Pintu Kabupaten Bone sangat jelas karena setiap pelayanan mempunyai alur pelayanan yang mudah dipahami, mudah dilaksanakan serta diwujudkan dalam bentuk bagang yang di pampang dalam ruang pelayanan karena sebagai petunjuk kerja bagi pemberi pelayanan, informasi bagi penerima pelayanan, media publikasi secara terbuka pada semua unit kerja pelayanan mengenai prosedur pelayanan kepada penerima pelayanan, pendorong terwujudnya sistem dan mekanisme kerja yang efektif dan efisien.

Analisis kejelasan persyaratan teknis dan administrasi pelayanan yaitu persyaratan yang harus dipenuhi oleh masyarakat dalam pelayanan, persyaratan tersebut harus di tampilkan secara jelas dan lengkap sesuai dengan ketentuan yang telah ditetapkan serta mudah dipenuhi oleh masyarakat. Dari hasil penelitian menunjukkan bahwa persyaratan teknis dan administrasi pelayanan pada di Dinas Penanaman Modal dan Pelayanan Satu Pintu Kabupaten Bone menampilkan dengan jelas kepada masyarakat. Persyaratan tersebut dinformasikan secara jelas dan diletakkan di dekat loket pelayanan, dapat dibaca dalam jarak pandang minimum 3 meter atau disesuaikan dengan kondisi ruangan.

Analisis kejelasan perincian biaya pelayanan yaitu kejelasan rincian biaya yang dikeluarkan dalam pengurusan, artinya bahwa masyarakat dapat mengkalkulasi besaran biaya yang akan dikeluarkan sesuai dengan ketetapan oleh Dinas Penanaman Modal dan Pelayanan Satu Pintu Kabupaten Bone. Dari hasil penelitian menunjukkan bahwa perincian biaya pelayanan sudah ditampilkan dengan jelas kepada masyarakat. jenis pelayanan yang dipungut biaya yaitu yang terkena retrtibusi seperti IMB dan Reklame, namun masih perlu adanya pembenahan sistem pelayanan sesuai dengan rekomendasi tarif yang ada di Dinas Penanaman Modal dan Pelayanan Satu Pintu Kabupaten Bone.

Analisis kejelasan pejabat berwenang dan bertanggung jawab yaitu pejabat dalam penyelenggaraan pelayanan dituntut untuk harus mampu 
menyelesaikan keluhan, persoalan dan sengketa serta memberikan kepedulian, kepastian pelayanan sehingga akan membangun citra positif terhadap masyarakat. Keberadaan dan kejelasan pejabat yang berwenang dan bertanggung jawab harus mampu memberikan solusi dalam pelayanan. Dinas Penanaman Modal dan Pelayanan Satu Pintu Kabupaten Bone sudah adanya kejelasan pejabat yang berwenang dan bertanggung jawab dengan tugas yang diberikan namun terkadang pejabat yang yang betugas tidak sepenuhnya memahami dan mengetahui apa yang mereka harus lakukan sehingga sangat dibutuhkan pelatihan yang dapat mendorong terlaksananya transparansi dan inovasi pelayanan publik demi mewujudkan kepuasan dan kesejahteraan masyarakat.

Analisis kejelasan janji pelayanan yaitu penerapan janji pelayanan merupakan komitmen pejabat yang berwenang dan bertanggung jawab dalam pelayanan untuk memberikan informasi secara tertulis dan jelas yang menyangkut tentang esensial yang didalamnya mengenai standar kualitas pelayanan. Berdasarkan dengan itu, janji pelayanan yang ada di Dinas Penanaman Modal dan Pelayanan Satu Pintu Kabupaten Bone harus diwujudkan dalam bentuk memberikan komitmen yang jelas secara tertulis dalam melayani masyarakat. sehingga memberikan kepastian dalam pelayanan serta memberikan perlindungan status hak pelayanan kepada masyarakat. Dengan adanya janji yang dapat ditampilkan jelas dalam pelayanan publik akan memberikan semangat, baik kepada pemberi maupun penerima layanan.

Analisis kejelasan standar pelayanan publik adalah suatu tolok ukur dari penyelenggara pelayanan kepada masyarakat untuk memberikan pelayanan yang berkualitas. Standar pelayanan minimal merupakan suatu kewajiban pejabat/pegawai untuk merumuskan dan menyediakan berbagai kepentingan masyarakat agar kenyamanan dalam pelayanan dapat tercapai. Berdasarkan hasil temuan dalam memberikan penjelasan dan informasi tentang standar pelayanan Dinas Penanaman Modal dan Pelayanan Satu Pintu Kabupaten Bone menampilkan dan mempublikasikan secara jelas standar pelayanan, dan adanya bentuk kepedulian dan komitman pejabat yang 
berwenang dalam menyusun suatu standar yang dapat dijadikan panduan dalam melayani masyarakat.

Analisis kejelasan lokasi pelayanan adalah tempat yang ditentukan dalam memberikan pelayanan, lokasi pelayanan harus jelas sehingga mereka tidak lagi bertanya-tanya kemana dan dimana mereka akan mendapatkan pelayanan. Lokasi pelayanan diusahkan harus tetap dan tidak berpindahpindah, mudah dijangkau oleh pemohon pelayanan, dilengkapi sarana dan prasarana yang memadai termasuk sarana telekomunikasi dan informatika (telematika). Hasil penelitian menunjukkan lokasi pelayanan Dinas Penanaman Modal dan Pelayanan Satu Pintu Kabupaten Bone sudah sangat jelas dengan adanya petunjuk dan arahan yang diberikan oleh bagian informasi di dinas tersebut sehingga mempermudah penerima layanan.

Analisis kejelasan Informasi dan pengaduan pelayanan adalah masukan dari masyarakat baik berupa informasi, saran, pendapat, tanggapan atau pengaduan, dalam upaya perbaikan pelayanan kepada pemberi pelayanan. Kejelasan informasi pengaduan dalam pelayanan di Dinas Penanaman Modal dan Pelayanan Satu Pintu Kabupaten Bone telah memberikan ruang kepada masyarakat untuk menyampaikan keluhan pelayanan yang dialaminya, pengaduan melalui kotak saran dan ada petugas yang langsung mendengarkan keluhan masyarakat. Organisasi pemberi pelayanan wajib menangapi dan menghadapi keluhan masyarakat tersebut untuk kepentingan dan kepuasan masyarakat itu sendiri. Transparansi di perlukan suatu proses konsultasi yaitu adanya dialog antara pemberi dan penerima layanan agar dapat memberikan saran dan keluhan terhadap pelayanan yang diberikan oleh penyelenggara pelayanan.

\section{Kendala yang dihadapi dalam peyelenggaraan pelayanan publik Di} Dinas Penanaman Modal Dan Pelayanan Satu Pintu Kabupaten Bone

Penyelenggaraan pelayanan di Dinas Penanaman Modal dan Pelayanan Satu Pintu Kabupaten Bone merupakan salah satu instansi yang bergerak dibidang pelayanan yang sangat membantu kebutuhan masyarakat mengenai 
Izin Mendirikan Bangunan, Izin Trayek, Izin Tenaga Kesehatan, Izin Sarana Kesehatan, Izin Penelitian, Izin Lingkungan, Izin Lokasi, Izin Reklame, Izin Usaha Jasa Konstruksi, Izin Usaha Pembudidayaan Ikan, SIUP dan TDP, Tanda Daftar perusahaan, Tanda Daftar Gudang dan IUI dan TDI. Dengan adanya pelayanan instansi ini dapat memberikan dampak atau hasil yang positif bagi pemecahan masalah yang dihadapi masyarakat. Namun disetiap pelayanan yang diberikan pasti meiliki kendala-kendala dalam menjalankan aktivitasnya, begitupun di Dinas Penanaman Modal Dan Pelayanan Satu Pintu Kabupaten Bone sering mengalami kendala dalam proses pelayanan. Beberapa kendala yang dihadapi yakni faktor jaringan internet yang tidak memadai sehingga waktu yang dibutuhkan dalam penyampain perizinan kepada penerima layanan sangat lambat.

\section{E. Kesimpulan dan Saran}

Dari hasil analisis transparansi penyelenggaraan pelayanan pada Kantor Dinas Penanaman Modal dan Pelayanan Satu Pintu Kabupaten Bone sudah terimplementasikan sesuai dengan apa yang diharapkan oleh masyarakat dari segi prosedur pelayanan; persyaratan teknis dan administrasi pelayanan; rincian biaya pelayanan; lokasi pelayanan; janji pelayanan; standar pelayanan dan, informasi pelayanan. Namun mengenai indikator yang menyangkut pejabat yang berwenang dan bertanggung jawab masih kurang karena masih ada beberapa aparat yang berwenang belum sepenuhnya mengetahui apa yang mereka harus lakukan sehingga sangat dibutuhkan pelatihan yang dapat mendorong terlaksananya transparansi dan inovasi pelayanan publik demi mewujudkan kepuasan dan kesejahteraan masyarakat. Kendala yang dihadapi yaitu faktor jaringang internet yang tidak memadai sehingga lamabat dalam proses penyelenggaraan pelayanan.

Adapun saran yang diberikan dalam penelitian ini yaitu perlunya pelatihan kepada para pegawai yang dapat mendorong terlaksananya transparansi dan inovasi pelayanan publik demi mewujudkan kepuasan dan kesejahteraan masyarakat. 


\section{DAFTAR PUSTAKA}

Amiruddin dan Zainal Asikin. 2008, Pengantar Metode Penelitian Hukum, Grafindo Persada, Jakarta.

Dwiyanto, Agus, 2008, Mewujudkan Good Governance Melalui PelayananPublik, Gajah Mada Univertity Press, Yogyakarta.

Lalolo Kriana P, 2003, Indikator dan Alat Ukur Prinsip Akuntabilitas, Transparansi dan Partisipasi, Sekertariat Good Public Governance, Badan Perencanaan Pengembangan Nasional, Jakarta.

Mustopadidjaja, 2003, Manajemen Proses Kebijakan Publik formulasi, Implemntasi dan Evaluasi Kinerja. Lembaga Administrasi Republik Indonesia.

Moleong, Lexy J, 2012, Metodologi Penelitian Kualitatif, Remaja Rosda Karya, Bandung.

Nico Adrianto, 2007, Good e-Governance: Transparansi dan Akuntabilitas Publik Melalui e-Governance, Bayumedia Publishing, Malang.

Syahruddin Nawi, 2014, Penelitian Hukum Normatif Versus Penelitian Hukum Empiris, PT Umitoha Ukhuwa Grafika, Makassar.

Suharsini Arikunto, 2010, Prosedur Penelitian Suatu Pendekatan Praktek, PT. Rineka Cipta, Jakarta.

Sugiyono, 2009, Metode Penelitian Kuantitatif, Kualitatif, dan R\&D Alfabeta, Bangdung.

Tahir, 2011, Kebijakan Publik dan Transparansi Penyelenggaraan Pemerintahan Daerah, PT. Pustaka Indonesia Press, Gorontalo

Zainuddin Ali, 2011, Metode Penelitian Hukum, SinarGrafika, Jakarta

\section{Undang-Undang}

Undang-Undang Nomor 9 Tahun 2015 tentang Perubahan Kedua atas Undang-Undang Nomor 23 Tahun 2004 tentang Pemerintahan Daerah (Lembaran Negara Republik Indonesia Tahun 2015 Nomor 58. Tambahan Lembaran Negara Republik Indonesia Nomor 5679).

Undang-Undang Nomor 25 Tahun 2009 Tentang Pelayanan Publik (Lembaran Negara Reublik Indonesia Tahun 2009 Nomor 112, Tambahan Lembaran Negara Republik Indonesia Nomor 5038).

Undang-Undang Nomor 5 Tahun 2014 Tentang Aparatur Sipil Negara (Lembaran Negara Republik Indonesia Tahun 2014 Nomor 6, 
Marjana Fahri, Analisis Transparansi Dalam Penyelenggaraan...

Tambahan Lembaran Negara Republik Indonesia Nomor 5494).

Keputusan Menteri Pendayagunaan Aparatur Negara No. 26 Tahun 2004 tentang Petunjuk Teknis Transparansi dan Akuntabilitas dalam penyelenggaraan pelayanan. 